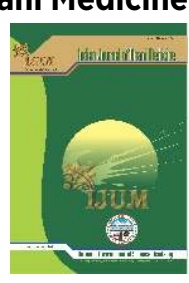

\title{
WARAM-I MEDA (GASTRITIS) AND ITS MANAGEMENT FROM UNANI PERSPECTIVE
}

\author{
Azma Waseem ${ }^{1 *}$, Waseem Ahmad ${ }^{2}$, Anwar Jamal', Mohammad Fazil ${ }^{3}$, Asim Ali Khan ${ }^{4}$ \\ ${ }^{1}$ Research Officer (U)/S-III, ${ }^{2}$ Technical Officer (U), ${ }^{3}$ Research Officer (U)/S-IV, ${ }^{4}$ Director General (CCRUM) \\ ${ }^{1,2,3}$ Hakim Ajmal Khan Institute for Literary \& Historical Research in Unani Medicine, CCRUM, New Delhi, India. \\ ${ }^{4}$ Central Council for Research in Unani Medicine, Janakpuri, New Delhi, India
}

\section{Review Paper}

Received: 08.10.2021

Revised: 19.10.2021

Accepted: 28.10.2021

\begin{abstract}
In the present scenario, gastritis still remains a major public health problem that affects the population of both the developed as well as developing countries. More than $50 \%$ of the population in developing countries suffers from gastritis, whereas $34.7 \%$ of the population in developed countries had health problems due to gastritis. Main causes of gastritis are infections, stress, continuous use of non steroidal anti-inflammatory drugs, alcohol and bile reflux. Gastritis if remains untreated or undiagnosed causes Quruh-i Meda (gastric ulcers). Prolonged and progressive inflammation results in destruction of gastric mucosa (Atrophic gastritis) and reduction in gastric acid secretions. These two factors are considered as the main risk factors in the pathogenesis of gastric cancer. Unani physicians have given much importance to this disease. In Unani system of medicine, there is elaborated description of gastritis under the heading of Waram-i Meda with causes, symptoms and its effective management. The fundamental principles of Unani treatment of gastritis is to restore the normalcy of the patient, correction of temperament (Mizaj ), humoral balance in the organ and the body, and toning up of the stomach. All these principles are achieved mostly by three modes of treatment i.e. Iaj bil Tadbeer (Regimenal therapy), Ilaj bil Ghiza (Dietotherapy) and Ilaj bil Dawa (Pharmacotherapy). In this review article, Waram-i Meda (gastritis) is elaborated with its type, causes and treatment in Unani perspective with the objective to reduce the burden of gastritis and prevention of complications associated with gastritis.
\end{abstract}

$\begin{array}{ll}\text { No. of Pages: } 7 & \text { No. of Tables: } 2\end{array}$

References: 22

Keywords: Gastritis, Waram-i Meda, Unani medicine.

\section{INTRODUCTION}

Gastritis is one the major gastrointestinal problems affecting worldwide population and it usually remains undiagnosed. More than $50 \%$ of the population of developing countries and $37 \%$ of the population in developed countries suffer from gastritis globally. More than $50 \%$ of the population in developing countries suffers from gastritis, whereas $34.7 \%$ of the population in developed countries had health problems due to gastritis ${ }^{(1)}$. Gastritis has received much attention in modern medicine after the discovery of the Helicobacter pylori in 1982, as this bacterium is found the main causative factor of gastritis in majority cases with exception of the autoimmune origin gastritis ${ }^{(2)}$. The significance of chronic gastritis as a serious disease is largely unvalued in clinical practice, even though the role of gastritis in the pathogenesis of ordinary peptic ulcers and gastric cancers is obvious ${ }^{(2)}$. It is more common in adolescents than older peoples and higher among women than men ${ }^{(3)}$. Normally, the lining of the stomach has protection against the irritating acid produced in stomach. Sometimes due to various reasons, the protective

*Corresponding author: azmawaseem34@gmail.com 
mechanism may become faulty, leading to discontinuity of the lining resulting in gastric inflammation and erosion and later ulceration if remain untreated. The aggressive factors include gastric juices, bile reflux, alcohol, infection, gastric mucosal ischemia, decreased bicarbonate secretion and use of Non Steroidal Anti Inflammatory Drugs (NSAIDs). These factors reduces mucosal defense ${ }^{(3,4)}$. It is more common in those who remain in hurry, anxious people and who consumes spicy food and take irregular diet. Certain life style factors and dietary factors such as skipping of diet or delaying in taking food, stress, consumption of tobacco, irregular intake of diet, alcohol, tea coffee or spicy foods, stimulates acid secretions which cause gastritis. Depending upon the severity, time, course and pathogenesis gastritis may be acute and chronic. Acute gastritis occurs suddenly persist for 2-3 days ${ }^{(1,2)}$. Histological studies demonstrated by marked filtrate of neutrophils with marked oedema and hyperemia in case of acute gastritis. Chronic gastritis occurs gradually last for long time and is responsible for gastric ulcer ${ }^{(3)}$. Chronic gastritis showing only very mild symptoms like discomfort and heaviness in the stomach. It is identified by inflammatory cell infiltration consisting of lymphocytes and plasma cells. Histological studies failed to demonstrate a significant association between gastritis and gastrointestinal symptoms, as gastritis does not always cause signs and symptoms ${ }^{(3)}$. However, in acute cases patients mainly complain of dyspepsia, gastrointestinal discomforts such as stomachache, bloating, nausea, vomiting, and loss of appetite. Multifocal atrophic gastritis, gastric atrophy with subsequent metaplasia, has been observed in $H$. pylori induced gastritis ${ }^{(4)}$. The molecular mechanisms and the role of environmental factors, like diet, and the role of other microbes than $H$. pylori on the course of chronic gastritis, are largely unknown ${ }^{(2)}$. So the individuals with gastritis are at risk of developing symptoms and certain complication such as gastric ulcers and gastric carcinoma, which have high morbidity and mortality ${ }^{(5)}$. Medicines that are used for the treatment of gastritis in conventional medicine are not very effective and show adverse effects on long term use ${ }^{(6)}$. In this context, Unani system of medicine can play an important role in reducing the burden of gastritis, which has been elaborately discussed by Unani physicians as Waram-i meda under the chapter on Amraz-i Meda (diseases of stomach/gastric diseases). In this review article, Waram-i Meda (gastritis) is discussed with its treatment following the general principles of treatment i.e. Taskeen, Tadeel-i Mizaj-i Meda, Tehleel-i Waram, Tanqiya-i Meda wa Taqwiyat-i Meda as per Unani perspective. Muhallil-i Waram (antiinflammatory) and Muqawwi-i Meda (stomachic) drugs are also mentioned for reference to carry out the research in this direction and to assess their potential role as an adjuvant therapy or alternative medicine in gastritis.
Concept of Waram-i Meda (Gastritis) in Unani Medicine:

In Unani system of medicine, gastritis is elaborated under the heading of Waram-i Meda. The word 'Waram' refers to inflammation and 'Meda' means stomach. Therefore the term "Waram-i Meda" refers to inflammation to the stomach lining tissue which may occur either instantly (acute) or gradually (chronic) ${ }^{(7,8)}$. As per the concept of Unani system of medicine, there are four humours in the body as postulated by Hippocrates. Health of a person depends on the qualitative and quantitative equilibrium of these four humours. The pathogenesis of diseases is attributed to, Mizaj (temperament), Tarkeeb (structural) and Ittesal (continuity). Any change or abnormality in these factors known as $\mathrm{Su}-\mathrm{i}$ Mizaj (morbid temperament/ temperamental dyscracia), Su-i Tarkeeb (structural abnormality) and Tafarruk-i ittesal (discontinuity in tissue) ${ }^{(9,10)}$. Waram is an example of compound disease which may occurs due to changes in all these three factors. Hence Waram-i Meda is a type of compound disease as per concept of Unani medicine.

\section{Asbab (causes) and Mahiyat-i Marz (pathogenesis) of Waram-i Meda:}

It occurs mainly due to excess of Hararat (heat), accumulation of Dam (Sanguine), Safra (Yellow bile), Balgham (Phlegm) or Sawda (Black bile) or Riyah (flatulence) in the stomach ${ }^{(11,12)}$. In the Mahiyat-i Marz of Waram-i Meda (pathogenesis of gastritis), Ibn Hubal Baghdadi has mentioned that sometimes morbid matter reaches to the stomach through vessels that provides food material to the stomach or morbid matter directly accumulated and putrefied in the stomach causes gastritis. Sometimes weakness of stomach is the cause of gastritis. In case of Zof-i Meda (weakness of stomach), stomach tissues and its layer become weak causing delayed in digestion of food and delayed clearing of duodenal contents that have refluxed in the stomach. It could damage gastric mucosa leading to gastritis and gastric ulceration ${ }^{(12)}$. According to Rabban Tabri, morbid matter that putrefied in the stomach is the main cause of gastritis ${ }^{(13)}$. Razi has mentioned in the prognosis of Waram-i Meda Haar (acute gastritis) that it resolves completely or convert into Waram-i Meda Muzmin (chronic gastritis), or leading to Qarha wa Buthur al-Meda (gastric erosion, or gastric ulcers) ${ }^{(14)}$. Sometimes, inflammation does not subside and leads to Dubayla-al meda or Khuraj al-Meda (suppurative gastritis) ${ }^{(15)}$.

Excessive use of hot water leads to gastritis by causing weakness of stomach. Intake of hot spicy food, excessive use of sweet diet, alcohol and less digestive diet, stimulates production of gastric secretions from the glands found in stomach which causes irritation and inflammation of gastric mucosa ${ }^{(7)}$. Sometimes gastritis may be associated with hyperurecemia, and other diseases like pneumonia, cholera, liver and renal diseases ${ }^{(7,16)}$. It may also occur due to presence of Jism-i Ghareeb (foreign body) in the stomach as seen in 
gastric tuberculosis, gastric carcinoma ${ }^{(7,9,12)}$. Whereas, the role of infection in gastritis gain attraction after the discovery of $H$. pylori in 1982, in conventional medicine ${ }^{(2)}$. Ibn Sina recognized the effects of gastritis on the other organs of the body. According to him, Ghashi (fainting) and Ghabrahat (palpitation) occurs in gastritis due to its effect on heart. Mental confusion and depression may be seen in gastritis ${ }^{(9)}$ due to upwards movement of morbid gases produced in the diseased stomach.

Types of Waram-i Meda (gastritis):

Ibn Hubal Baghdadi ${ }^{(12)}$ has classified Waram-i Meda as:

1. Waram-i Haar (Acute gastritis): It includes Waram-i Meda Damawi (Sanguinous gastritis) and Waram-i Meda Safrawi (bilious gastritis).

2. Waram-i Barid (Chronic gastritis): It is further sub-divided as Balghamī or Rikhw (phlegmatic gastritis) or Sawdawi or Sulb (melancholic type or gastritis of hard consistency).

3. Waram-i Meda Reehi (gaseous gastritis): Gastritis that occurs due to gaseous collection.

Hakim Azam Khan ${ }^{(16)}$ has categorized Waram-i- Meda into various types, depending upon the causative factor and severity:

(A) Types of Waram-i Meda on the basis of temperamental dyscracia:

i. Waram-i Meda Sada (gastritis due to impairment of simple temperament): In this condition, gastritis occurs due to Su-i Mizaj Sada (simple impairment in the temperament) i.e. due to predominance of Hararat (heat), Burudat (cold), Rutubat (moistnes) or Yubusat (dryness) in the stomach. Mostly, it is caused by predominance of Hararat (heat) ${ }^{(7)}$. It may be secondary to liver disease due to the close association of stomach with liver. General principle of treatment of this type of gastritis is Ilaj bil Zidd (heterotherapy). For example in case of predominance of heat, altered temperament is corrected through adopting cold measures such as cold diet like pursalane, curd prepared with cow milk, pomegranate juice is recommended ${ }^{(12,15,16)}$.

ii. Waram-i Meda Maddi (gastritis due to humoral imbalance): It is of four types depending upon the causative humour $^{(16)}$ :

- Waram-i Meda Damvi (gastritis due to predominance of sanguine/ sanguineous gastritis)

- Waram-i Meda Safravi (gastritis due to predominance of bile/ bilious gastritis)

- Waram-i Meda Balghami (gastritis due to predominance of phlegm/phlegmatic gastritis)
- Waram-i Meda Sawdavi (gastritis due to predominance of black bile/Melancholic gastritis)

(B) Most of the Unani scholars have categorized Waram-i Meda (gastritis) as ${ }^{(7,9)}$ :

i. Waram-i Meda Haar (acute gastritis)

ii. Waram-i Meda Muzmin (Chronic gastritis)

iii. Waram-i Meda Sulb (gastritis of hard consistency)

Alamaat wa Usool-i Ilaj (Clinical Features \& General Principles of Treatment) of Waram-i Meda:

i. Waram-i Meda Haar (acute gastritis): It includes gastritis due to predominance of Dam (sanguine humour) or Safra (yellow bile) ${ }^{(12)}$. Main features of this type of gastritis is epigastric pain ${ }^{(8,9)}$ which increases on coughing, after eating and in lying position, and swelling is felt on palpation particularly when inflammation is present in antral part of the stomach. Other symptoms are nausea, vomiting, anorexia, alternate diarrhea or constipation, headache, redness (in case of sanguine predominance) or yellowish discolouration of face, excess of thirst restlessness and weakness (in case of bilious gastritis) ${ }^{(7)}$. Fever is usually present ${ }^{(8)}$. Waram-i Meda (gastritis) may lead to Zof-i Hazm (delayed digestion). In children, if the inflammation reaches to intestines, it leads to diarrhea ${ }^{(7)}$. Sometimes it may cause mental confusion, meningitis and depression. Presence of mild, fever, epigastric pain, foul smelling belching and presence of blood, pus or mucus in the vomitus and stool indicates ulceration in the stomach ${ }^{(15)}$. For this type of gastritis, general principles of treatment are Taskeen-i Alam (to relief gastric pain), Istafragh-i Madda (evacuation of morbid humour) and Tahleel-i Waram (to reduce inflammation) ${ }^{(15)}$. To alleviate pain Tamreekh is done with Roghan Safarjal, post Kadu shireen, and Arad-i Jaw. Takmeed Haar (hot fomentation) also helps in alleviation of pain ${ }^{(9)}$. For predominance of sanguine matter bloodletting through basilica vein ${ }^{(9,14)}$ or Akhal Vein ${ }^{(12)}$ is advised followed by oral administration of pomegranate juice and Ma al-Shaeer (barley water) ${ }^{(15)}$. According to some physician, Hijamah (Cupping) is also beneficial to reduce gastralgia ${ }^{\left({ }^{(1)}\right.}$. Qay (emesis) is contraindicated in acute gastritis ${ }^{(17)}$. For reduction of inflammation, drugs having Rade (repellant), Muhallil-i Waram (anti-inflammatory) and Muhallil (resolvant) pharmacological activities are used for oral administration and local application ${ }^{(14,15)}$. Repellant drugs prevent Insibab-i Madda (absorption/ accumulation of morbid matter in stomach), antiinflammatory drugs reduce inflammation and resolvant drugs help to resolve thick and viscous humours present in the stomach. Skipping of meal if possible or very light dietary items like Maa al-Shaeer (barley water), moong dal (moong pulse), bathwa (goose berry), khichrii, palak 
(spinach), kadu (cucurbita), khurfa (common purslane), safarjal (golden apple), seb (apple), angoor (grapes) are recommended in the diet ${ }^{(8,9,15)}$. Harira (sweet preparation) prepared with wheat husk, sugar and almond oil is also beneficial. Barg-i chuqandar (beet root leaves) is also useful ${ }^{(8,12)}$. Sweet, salty and spicy diet, alcohol and meat should be avoided ${ }^{(16)}$.

ii. Waram-i Meda Muzmin (Chronic gastritis): Phlegmatic gastritis included in this category. Either the acute gastritis converts into chronic gastritis, or it develops gradually due to Zof-i Meda (weakness of stomach) or accumulation of balgham (phlegm) in the stomach ${ }^{(8,14)}$. In chronic gastritis gastric mucosa becomes thick and grayish. There may found erosion or hemorrhagic points in the gastric mucosa. Stomach somehow increases in size and there is found increase mucoid secretion rather than gastric acid or juices. Main characteristic features of chronic gastritis are mild fever, mild pain, excessive salivation and stomatitis, belching, hiccup, loss of appetite, gastric distension and tenderness in epigastric region but no hardness is found on palpation ${ }^{(9)}$. Face becomes pale or whitish and odema may be present ${ }^{(7)}$. Patient becomes lazy, lethargic, weak and complaints of passage of concentrated urine and reduced frequency ${ }^{(15)}$. From the recent studies, it is clear that in chronic gastritis (acid-free and atrophic stomach), due to the impairment in secretion of intrinsic factor, absorption of the essential vitamins, like vitamin B12, are severely failed and dietary metabolism and absorption of micronutrients, likeiron, calcium, magnesium and zinc are also affected leading to weakness, mental confusion, etc ${ }^{(2)}$. Its principle of treatment is Istafragh-i Balgham (evacuation of morbid phlegm), Taqwiyat-i Meda (to tone up stomach) and removal of the root cause. For removal of morbid phlegm Munzij Mushil therapy (concoction and purgation). Concoctive drugs are used before purgative drugs to modify the madda (matter) so that it can be excreted out easily ${ }^{(16)}$. Purgative drugs are recommended to eliminate the morbid matter through purgation. After this therapy, Tabreed (to produce calming effect) is recommended ${ }^{(15)}$ to reduce its drying effect. Riyazat Khafeef (Light exercise) is advised ${ }^{(11)}$. In Ilaj bil Ghiza (dietotherapy), food in small quantity and light diet is recommended ${ }^{(15,16)}$. Food stuff that are beneficial in this type of gastritis are Sirka (vinegar), Roghan Zaitoon (olive oil), Khubbazi (mallow), Chuqandar (beet root), gravy prepared with small birds meat like Batair (Common partridge) and Teetar (partridge $)^{(12,16)}$.

iii. Waram-i Meda Sulb (gastritis of hard consistency): Gastritis due to black bile included in this category. It develops due to non resolution of Waram-i Meda Haar (acute gastritis) or Waram-i Meda Muzmin (chronic gastritis). It may occur due to predominance of black bile in the stomach. In Unani system of medicine morbid sawda is the main culprit humour behind the cancer ${ }^{(12)}$. Gastritis association with malignancy has mentioned in Unani medicine with reference to an ancient physician Rabban Tabri ${ }^{(7)}$. Recent research studies also confirmed that chronic and active gastritis will result in destruction of stomach mucosa and dysfunction of the gastric epithelium. Some of the alterations are reversal, may appear even at early stages of inflammation, but may particularly accumulate with time in premalignant conditions, such as atrophy, precancerous and malignant lesions ${ }^{(2)}$. Main feature of this type of gastritis is hardness in epigastric region on palpation, blackish discolouration of face, loss of weight and dryness of the skin and dry eyes, mental confusion, nightmares, and irritability with other symptoms of gastritis ${ }^{(9,12)}$. General principles of treatment of this type of gastritis is Istafragh-i Sawda (evacuation of morbid black bile), Tahleel-i Waram (to reduce swelling). Munzij wa Mushil-i Sawda (concoctive and purgation of morbid black bile) is advised as regimental therapy ${ }^{[12]}$. For softening and resolution of swelling Zimad Mulayyina wa Muhallila (paste prepared with drugs having softening and resolvant properties) are used locally. Such type of Muhallil (resolvant) drugs are advised which have mild astringent properties and are aromatic ${ }^{(9)}$. Light diet like chicken soup, Halyun (Asparagus), Oont ka dudh (camel's milk), Khubbazi (mallow/ blue mallow) and almond oil is advised. Besides this, Harira (semi liquid sweet preparation) prepared with Sheera Qurtum (Carthamus tinctorius Linn.), butter, wheat husk is also beneficial ${ }^{(12)}$. If Qarha Humudi (gastric ulcer) develops as a complication, is treated by adopting the treatment principles such as Tanqiya-i Quruh (cleansing of ulcers) with the drugs like Ma al-Asal (honey water), Istafragh-i Madda (removal of causative humour) with Mulaiyyinat (laxatives), Indemal-i Quruh (to heal ulcer) with the use of drugs having wound healing properties and Taqwiyat-i Meda (to tone up the stomach) with the use of Muqwwiyat-i Meda (stomachic) ${ }^{(14,16)}$.

\section{Drugs useful in the management of Waram-i Meda (gastritis)}

In Unani Medicine various plant origin drugs and their extracts are mentioned for the treatment of gastritis. Scientifically the extracts of plants are considered as important sources of new molecules that showed positive results in cure of gastritis. It is also proven that antioxidant potential of medicinal plants also helps for exhibiting the antiulcer activity due to the presence of various phytochemical constituents like tannins, gums, flavonoids, saponins, etc. in different parts of the plants. 
Unani drugs recommended for Waram-i Meda Haar (acute gastritis)

\section{Single drugs:}

Post Khashkhash (rind of Papaver somniferum Linn.) boiled in Araq Gulab is used for hot fomentation ${ }^{(7)}$.

Use of decoction of Raihan (Ocimmum sanctum Linn) as Natool (pouring of water at some distance). Bajra seeds tied in a cloth (Pennissetum glaucum R. Br.) are used for hot and dry fomentation to relieve pain ${ }^{(12)}$.

$\square$ Aab-i Mako sabz Murawwaq (leaf extracts of Solomon Nigrum Linn.) is given orally ${ }^{(8,16)}$

Aab-i Kasni Murawwaq (leaf extract of Cichorium intybus Linn.) administered orally ${ }^{(9)}$.

Maweez (Vitis vinifera), Bihidana (Cydonia oblonga Mill.) and Sibr (Aloe vera) is used orally ${ }^{(9,17)}$

$\square$ Khaksi (Sisymbrium altissimum L.) is used orally for fever associated with gastritis ${ }^{(7,16)}$.

$\square$ Maghz Faloos Khayar Shanbar (fruit pulp of Cassia fistula Linn.) is used for oral and local application ${ }^{(7)}$.

Rade (repellant) drugs like Gil Armani (Armenian bole), Gulab (Rosa damascena Mill.), Rasaut (Berberis aristata DC.) are used in form of paste for local application over abdomen in initial stage ${ }^{(9,16)}$.

$\square$ Drugs like Kundur (Boswellia serrata Roxb.), Khatmi (Althaea officinalis Linn.), Mastagi (gum of Pistacia lentiscus Linn.), Arad-i Jaw (flour of Hordeum vulgare Linn.), Babuna (Matricaria chamomilla Linn.), Nakhuna (Melilotus alba Desr.), Zarr-i Ward (pollens of Rosa damascena Mill.) are used for local application in last stage of inflammation ${ }^{(16)}$.

Compound drugs:

$\square$ Sharbat Banafsha ${ }^{(12)}$

$\square$ Araq Mako, Qurs Tabasheer, Sharbat Bazuri, Gulqand (16)

$\square$ Sharbat Nilofar ${ }^{(15,16)}$

$\square$ Sikanjbeen is given orally in last stage of inflammation $(12,16)$

Drugs useful in Waram Meda Muzmin/ Warm-i Rikhw (chronic/phlegmatic gastritis) $^{(7,916)}$ :

\section{Single drugs:}

Tukhm-i Kadu (Cucurbita moschata (Duchesne) Poir)

Heeng (Ferula foetida regel)

Aab-i Inab al-Salab (extract of Solanum nigrum Linn.)

Sana Makki (Cassia angustifolia Linn.)

Zanjabeel (Zingiber officinale Roscoe)

Zufa Khushk (Hyssopus officinalis Linn.)

Anjeer Khushk (Ficus carica Linn.)

Aab-i Badiyan (Foeniculum vulgare Mill.) and Asal alSoos (Glycyrrhiza glabra Linn.) for oral use.

\section{Compound drugs:}

Tiryaq-i Arba ${ }^{(7)}$

$\square \quad$ Maa al-Usool with Gulqand or Dawa al-Kurkum ${ }^{(11)}$

Roghan Yasmeen or Roghan Gul with sirka (vinegar) used locally on abdomen ${ }^{(16)}$.

For Waram-i Meda Sulb (gastritis with hard consistency) ${ }^{(7,}$ 16).

Single drugs:

Elwa (Aloe vera)

$\square$ Badiyan (Foeniculum vulgare Mill.)

Faloos Khayar Shanbar (pulp of Cassia fistula Linn.)

$\square$ Karafs (Apium graveolens Linn.)

Tukhm Raihan (Ocimum sanctum Linn.)

Gul Surkh (Rosa damascena Mill.) and Kasoos (Cuscuta reflexa Roxb.) are used for oral administration.

\section{Compound drugs}

Maa al-Usool ${ }^{(16)}$

Qurs Ward, Ayarij Loghazia, Ayarij Arkaghanees, Itrifal Sagheer and Majoon Gul $^{(16)}$

Rub/Araq Afsanteen, Araq Badiyan ${ }^{(15,17)}$, Araq Ghekwar ${ }^{(16)}$, Rub Ghafis ${ }^{(17)}$

$\square$ Roghan Bed Anjeer (castor oil) (7) and Roghan Qust/ Roghan Nardain used locally ${ }^{[15,16]}$

Drugs for local application in form of paste $e^{(9,12,16)}$ :

$\square$ Sunbulal-Teeb (Nardostachys Jatamansi (D.Don) DC.)

$\square \quad$ Methi (Trigonella foenum graecum Linn.)

$\square$ Bazr-i Katan (seed of Linum usitatissimum Linn.)

$\square$ Babuna(Matricaria chamomilla Linn.)

$\square$ Qurtum (Carthamus tinctorius Linn.)

$\square \quad$ Afsanteen (Artemisia absinthium Linn.)

Karnab (Brassica olearacea L.), Mom (Wax)

\section{Muqawwiyat-i Meda (Stomachic):}

The concept of strengthening organs of the body is very much elaborated in Unani system of medicine. Strong and toned organs are not affected easily with excessive heat or cold and morbid humours. If somehow morbid humours are diverted toward the healthy organ are absorbed and resolved easily. Single and compound drugs as Muqawwiyat Meda (stomachic) are described which strengthen or tone up the stomach. These drugs also strengthen other organs such as liver, heart and intestines. Some stomachic drugs are mentioned below ${ }^{(18,19,20)}$ : 


\begin{tabular}{|c|c|c|}
\hline S. No. & Single Drugs & Botanical name \\
\hline 1. & Afsanteen & Artimissia absinthium Linn. \\
\hline 2. & Amla & Emblica officinalis Gaertn, \\
\hline 3. & Anar & Punica granatum Linn. \\
\hline 4. & Badiyan & Foeniculum vulgare Mill. \\
\hline 5. & Bihi/ Bihidana & Cydonia oblonga Miller. \\
\hline 6. & Bisbasa & Myristica fragrans Houtt. \\
\hline 7. & Belgiri & Aegle marmelos L. \\
\hline 8. & Darchini & Cinnamomum zeylanicum Blume \\
\hline 9. & Halayla Zard & Terminalia chebula Ritz. \\
\hline 10. & Jamun & Syzygium cuminii (Linn.) Skeels \\
\hline 11. & Kamun & Cuminum cyminum Linn. \\
\hline 12. & Marw/Kanocha & Phyllanthus maderaspatensis Linn. \\
\hline 13. & Nankhwah & Trachyspermum ammi (Linn.) Sprague \\
\hline 14. & Naar Mushk & Mesua ferrea Linn. \\
\hline 15. & Nagarmoth & Cyperus rotundus Linn. \\
\hline 16. & Nankhwah & Trachyspermum ammi (Linn.) Sprague \\
\hline 17. & Pudina & Mentha arvensis Linn. \\
\hline 18. & Qaranful & Syzygium aromaticum Linn. \\
\hline 19. & Seer & Allium sativum Linn. \\
\hline 20. & Zanjabeel & Zingiber officinale Roscoe \\
\hline
\end{tabular}

Compound drugs that are used as Muqawwi-i Meda (Stomachic) are as follows ${ }^{(19,21,22)}$ :

\begin{tabular}{|l|l|l|}
\hline S. No. & Compound drugs & Dose \\
\hline 1. & Habb Hilteet & 2 tablet twice a day. \\
\hline 2. & Itrifal Zamani & $5-10$ gm before sleep. \\
\hline 3. & Jawarish Amla & $5-10$ gm twice a day \\
\hline 4. & Jawarish Bisbasa & $5-10$ gm daily. \\
\hline 5. & Jawarish Jalinoos & $5-15$ gm (in divided doses) daily. \\
\hline 6. & Jawarish Kamuni & $5-7$ gm daily. \\
\hline 7. & Jawarish Tamarhindi & $5-10$ gm daily. \\
\hline 8. & Jawarish Zanjabeel & $5-10$ gm daily \\
\hline 9. & Majoon Habbul Ghar & 4.5 gm per day. \\
\hline 10. & Majoon Maluki & 4.5 gm per day. \\
\hline 11. & Murabba Utraj /Murabba Turanj & As directed by physician. \\
\hline 12. & Qurs Tabasheer Qabiz & $3-5$ gm daily (in divided doses). \\
\hline 13. & Qurs Mushk & 4.5 gm daily (in divided doses). \\
\hline 14. & Safoof Ood & 4.5 gm daily along with Gulqand Aftabi. \\
\hline 15. & Safoof Nana & $3.5-9$ gm daily in divided doses. \\
\hline 16. & Sikanjbeen Safarjali & As directed by physician. \\
\hline
\end{tabular}




\section{CONCLUSION}

Waram-i Meda is a term which has been used by the ancient Unani physicians in an attempt to explain the gastritis applicable to present day etymology. From the above review, it can be concluded that the recommendations of Unani physicians regarding principles of treatment, life style and dietary modifications along with treatment with drugs can be adopted for the management of gastritis, improvement of quality of life and prevention of complications associated with gastritis. The drugs mentioned in the article have a clear evidence of their potential in the treatment of gastritis. There is a need to undertake rigorous research on Unani drugs by adopting standard, reliable and scientific parameters for acceptance of efficacy of Unani drugs at scientific level and to highlight the strength of Unani medicine in reducing the burden of gastritis. Further studies on single as well as compound drugs are also needed to identify the bioactive compounds responsible for their pharmacological activities and therapeutic uses in gastritis.

\section{REFERENCES}

1. Feyisa ZT, Woldeamanuel BT. Prevalence and associated risk factors of gastritis among patients visiting Saint Paul Hospital Millennium Medical College, Addis Ababa, Ethiopia. PLoS ONE. 2021; 16(2): e0246619.

2. Sipponen $\mathbf{P}, \&$ Maaroos HI. Chronic gastritis, Scandinavian Journal of Gastroenterology. 2015; 50: 657-667.

3. Hans-Peter $W$, and Yang $M$. Different Pathophysiology of Gastritis in East and West? A Western Perspective. Inflamm Intest Dis 2016; 1:113-122. pmid:29922666.

4. Fauci KB, Jameson HL. Harrison's Principles of Internal Medicine. Vol II, $16^{\text {th }}$ Ed. McGraw-Hill, Medical Publishing Division, USA. 2005.p 1760-62.

5. Ramakrishnan K., Peptic ulcer disease. Am Fam Physician 2007; 76(7): 1005-1012.

6. Gabriel SE, Jaakkimainen L, Bombardier CS. Risk for serious gastrointestinal complications related to the use of non steroidal anti-inflammatory drugs-A metanalysis. Ann Intern Med.1991;115:787-96.

7. Kabiruddin M. Tarjuma Sharah Asbab wa Alaamat, Vol II, Mohd. Basheer and Sons, Old Delhi. YNM; pp 202-205.
8. Qamari N. Ghina Muna (Arabic), CCRUM, New Delhi. 2008; pp 90-93.

9. Ibn Sina. Al-Qanun fil Tibb Vol III, part I, Daira Kitab al-Shifa Dariyaganj, New Delhi. 1993; p. 331-323, 370374.

10. Ahmad SI. An Introduction to al-Umoor al-Tabiyah, Principles of Human Physiology in Tibb., Central council for research in Unani medicine, New Delhi. 2009, pp. 180-181.

11. Tabri AHAM. Al-Mualajat al-Buqratiyya,(Urdu Translation), Part III, CCRUM, New Delhi, 1995; pp.139-146.

12. Baghdadi IH. Kitab al-Mukhtarat fil-Tibb, Vol-III, CCRUM, New Delhi. 2005; pp. 204-205, 231-234.

13. Tabri R. Firdaus al-Hikmat, Urdu translation by Suhaib Siddiqui, Faisal Brothers, Dariyaganj , New Delhi. 2002; p 199.

14. Razi ABMZ. Kitab al Fakhir, Central Council for research in Unani Medicine, New Delhi. 2005; pp. 280299.

15. Majusi AA. Kamil al-Sana al-Tibbiyya, Vol. II, CCRUM, New Delhi, 2005; pp. 337-338.

16. Khan MA. Ikseer-i Azam Vol. I, Matba Nami Munshi Naval Kishore, Lucknow. 1906; p.488-502.

17. Ahmad HJ. Tazkira Jaleel, CCRUM, New Delhi. 2008; pp 220-222.

18. Baghdadi IH. Baghdadi IH., Kitab al-Mukhtarat filTibb, Vol-II, CCRUM, New Delhi.2005; pp. KM II pp. 50, 63, 100,201,202,204,244,187-88, 332,391.

19. Shirazi MMS. Makhzan Al-Adviya, (Persian), Akmal al-Mat'aba, Delhi. 1278 H; pp. 92-93109, 131, 179, 200, 283, 618, 620, 627,327.

20. Kabiruddin M. Makhzan al-Mufradat, Aijaz Publishing House, New Delhi. 2000; pp.14, 54, 93, 216, 144, 170, 265, 322,565, 590 .

21. Anonymous. National Formulary of Unani Medicine, Vol. I, CCRUM, New Delhi. 1993; pp. 54, 97, 161-162, 164, 166, 167, 174-75, 176, 220, 350.

22. Arzani MA. Qarabadeen-i Qadri (Urdu), Central Council for Research in Unani Medicine, New Delhi. 2009; pp. 322, 327, 261, 375-76. 